\title{
Spatially explicit decision support for selecting translocation areas for Mojave desert tortoises
}

\author{
Jill S. Heaton • Kenneth E. Nussear • Todd C. Esque • \\ Richard D. Inman · Frank M. Davenport · Thomas E. Leuteritz • \\ Philip A. Medica $\cdot$ Nathan W. Strout $\cdot$ Paul A. Burgess • \\ Lisa Benvenuti
}

Received: 20 February 2007 / Accepted: 24 October 2007 / Published online: 25 January 2008

(C) Springer Science+Business Media B.V. 2008

\begin{abstract}
Spatially explicit decision support systems are assuming an increasing role in natural resource and conservation management. In order for these systems to be successful, however, they must address real-world management problems with input from both the scientific and management communities. The National Training Center at Fort Irwin, California, has expanded its training area, encroaching U.S. Fish and Wildlife Service critical habitat set aside for the Mojave desert tortoise (Gopherus agassizii), a federally threatened species. Of all the mitigation measures proposed to offset expansion, the most challenging to implement was the selection of areas most feasible for tortoise translocation. We developed an objective, open, scientifically defensible spatially explicit decision support system to evaluate translocation potential within the Western Mojave Recovery Unit for tortoise populations under imminent threat from military expansion. Using up to a total of 10 biological, anthropogenic, and/or logistical criteria, seven alternative translocation scenarios were developed. The final translocation model was a consensus model between the seven scenarios. Within the final model, six potential translocation areas were identified.
\end{abstract}

Keywords Conservation and management · DSS · Geographic Information Systems · GIS · Gopherus agassizii · Mitigation · National Training Center at Fort Irwin · Threatened species

J. S. Heaton · F. M. Davenport · T. E. Leuteritz - N. W. Strout · P. A. Burgess · L. Benvenuti Redlands Institute, University of Redlands, 1200 E. Colton Ave., Redlands, CA 92373-3755, USA

K. E. Nussear · T. C. Esque · P. A. Medica

Western Ecological Research Center, United States Geological Survey, Biological Resources Division, Las Vegas Field Station, 160 N. Stephanie St., Henderson, NV 89074-8829, USA

R. D. Inman

Department of Biology, University of Nevada, Reno, MS 314, 1664 N. Virginia St., Reno, NV 89557-0001, USA

Present Address:

J. S. Heaton $(\bowtie)$

Department of Geography, University of Nevada, Reno, MS 154, 1664 N. Virginia St., Reno, NV 89557-0001, USA

e-mail: jheaton@unr.edu 


\section{Introduction}

Decision support systems play an increasing role in natural resource and ecosystem management (Leung 1997) including forest management practices (Rauscher 1999; see recent special issues in Forest Ecology and Management 207:2005 and Computers and Electronics in Agriculture 49:2005), coral reef development (Meesters et al. 1998), aquatic and riparian conservation planning (Reeves et al. 2006), road system analysis in national forests (Girvetz and Shilling 2003), sustainable agriculture (Riordan and Barker 2003), and prioritization of sites for restoration planning in a variety of habitats (Llewellyn et al. 1996; Twedt et al. 2006). The increasing popularity of decision support systems in natural resource and ecosystem management stems from (1) the need to balance increasingly complex multiple land use constraints under current management strategies; and (2) the evolution of computer systems designed to utilize data and generate models to solve management problems. While these systems had rudimentary capabilities in the 1970s (Sprague 1986), today's more complex systems incorporate Geographic Information Systems (GIS), multi-criteria analysis, and fuzzy logic, allowing users to systematically explore alternatives and uncertainty in data, resolve conflicts, and access voluminous scientific information. Conflict resolution is possible because costs and benefits can be explored and alternates readily compared. Decision support systems allow all interested parties to participate and share knowledge of details in a systematic, consistent manner. The final products allow prioritization of management decisions based upon costs and feasibility while providing a process open to the scrutiny of all parties involved.

The National Training Center (NTC) at Fort Irwin, California, is a large $\left(2,598 \mathrm{~km}^{2}\right)$ Department of Defense force-on-force training area. In 2001 the National Defense Authorization Act (Public Law 107-314 2002) added $545 \mathrm{~km}^{2}$ of new training lands to the NTC. Approximately two-thirds of the expansion encroaches critical habitat designated for the desert tortoise (U.S. Fish and Wildlife Service 1994b) and the Western Mojave Recovery Unit (U.S. Fish and Wildlife Service 1994a) in which tortoise populations face the greatest number of challenges and obstacles to recovery (Tracy et al. 2004). Of all the recommended mitigation measures (U.S. Fish and Wildlife Service 2004), the most challenging to implement is the translocation of an estimated 2,000 desert tortoises from portions of the expansion area.

Esque et al. (2005) stressed the need for development of a scientifically credible process to identify suitable areas for translocation of desert tortoises. Because science and management objectives sometimes differ, alternative scenarios were needed to test assumptions of the relative importance of model criteria and allay concerns about data uncertainty. To this end, we developed an interactive, spatially explicit decision support system designed to communicate ecological concepts and decision implications. The objectives of this research were: (1) develop an objective, open decision support system to rank landscape suitability for translocation based on multiple habitat and conservation criteria; (2) provide a range of scenarios to accommodate differences of opinion, possible alternative management actions, and uncertainty in data or the effect of ecological processes; and (3) use this decision support system to identify optimal translocation sites for some 2,000 desert tortoises under imminent threat of NTC expansion. 


\section{Methods}

Study area

The area for prospective translocation covered $20,581 \mathrm{~km}^{2}$ surrounding the National Training Center at Fort Irwin (NTC) in southern California, USA, including three desert tortoise Critical Habitat Units-Fremont-Kramer, Superior-Cronese, and Ord-Rodman (Fig. 1). The study area was subdivided into $2.59 \mathrm{~km}^{2}$ cells that served as units of analysis. The area of each cell was equivalent to one U.S. Public Land Survey System section, typically referred to in statutory units of $1 \mathrm{mi}^{2}$. This unit size was chosen at the request of the decision makers for the purpose of identifying Public Land Survey System sections that could be purchased to fulfill the land acquisition mitigation measure. We scaled all data sets to this cell size.

\section{Technological framework}

The criteria, relationships between criteria, and criteria weights used to evaluate the translocation potential of a site were documented in NetWeaver (Saunders et al. 2005). Using fuzzy logic (Zadeh 1968), we parameterized these criteria, assigning them truth values which ranged from -1 to 1 , where 1 was considered completely suitable, and -1 completely unsuitable. We then weighted each criterion according to its relative importance

(a)

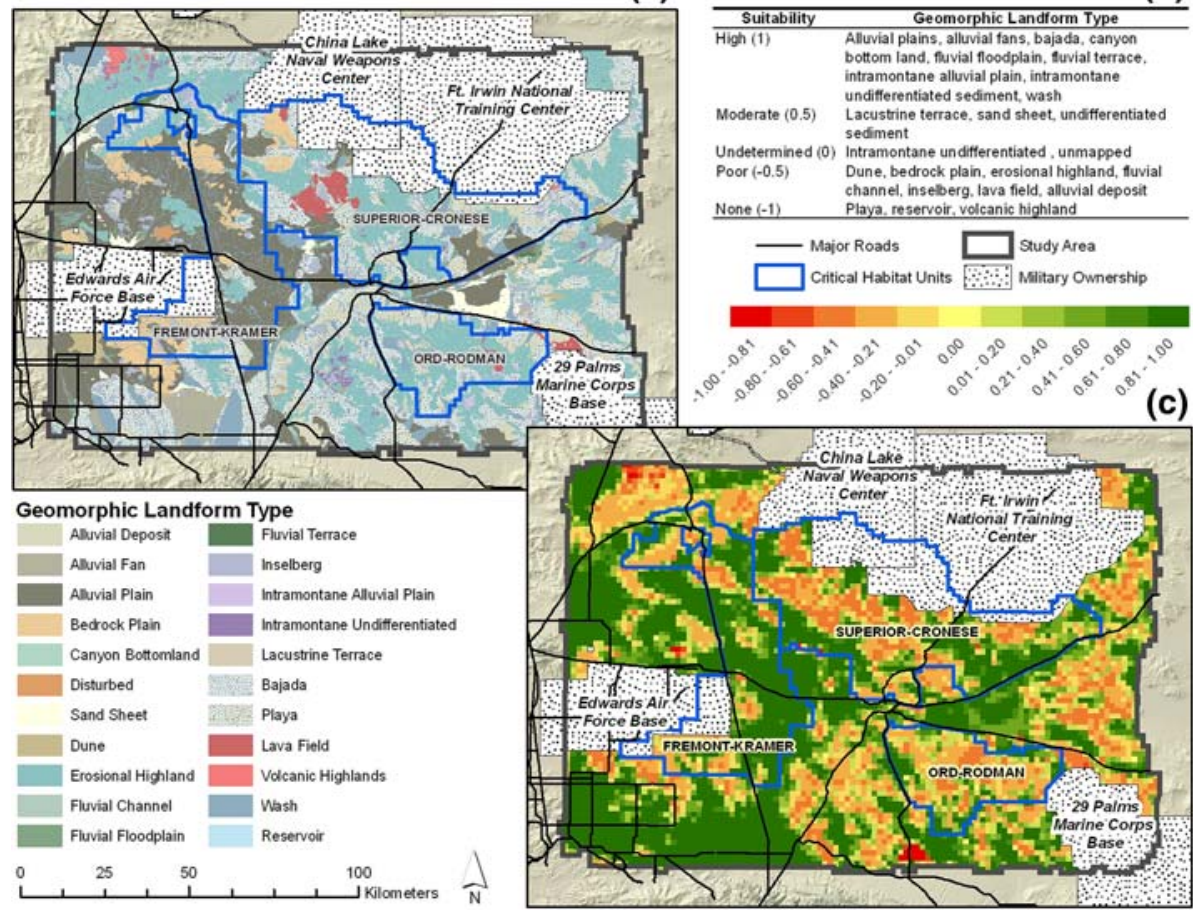

Fig. 1 Habitat criteria. (a) Map showing habitat source data, geomorphology. (b) Habitat landform model parameters. (c) Suitability for translocation based upon habitat. Habitat suitability grades from least suitable (red) to most suitable (green) 
based upon expert opinion. The fuzzy logic framework accommodates uncertainty commonly lost in ecological modeling under traditional mathematical models (Openshaw 1996; Reynolds 2001). For example, species distributional limits may be gradual rather than abrupt, or knowledge of these precise limits may be incomplete (Meesters et al. 1998). For every scenario, each section was assigned a truth value related to the degree to which that section was predicted to be suitable for translocation given the combined suitability of all the criteria at that location.

We pre-processed all data for developing the criteria using customized ESRI ArcGIS geoprocessing models. Spatial models for each criterion and all criteria combined were run within the Ecosystem Management Decision Support (Reynolds 2001) ArcGIS extension. Ecosystem Management Decision Support provides a framework for open and spatially explicit decision support modeling in ecological investigations at multiple geographic scales (Reynolds et al. 1996, 2003; Reynolds and Hessburg 2005). The GIS framework allowed us to ask questions of the data and management actions in the form of alternative scenarios.

\section{Model criteria}

The criteria selected for prioritizing potential translocation sites included biological and anthropogenic factors affecting desert tortoise populations in the Western Mojave Desert Recovery Unit, as well as logistical constraints. Criteria thought to be important for translocation, along with their model parameters and model weights, were identified in a draft report (Esque et al. 2005). Ten criteria were selected for assessing translocation suitability. Our interpretation of these criteria as good or bad depended on the individual scenario objectives. To start, we developed a base scenario followed by six alternative scenarios. Data sources for the 10 criteria are provided in Table 1 and their suitability for translocation as modeled in the base scenario was as follows.

\section{Ownership}

The purchase of private lands within desert tortoise critical habitat was a mitigation measure for expansion. Private lands with many owners are more difficult to purchase than contiguous blocks of land with fewer owners. Because extensive tracts of federal and state lands suitable for translocation existed within the study area, privately held sections were considered less suitable. However, within privately held sections, those with fewer land owners and those surrounded by existing public lands were considered more suitable.

Habitat

Although general knowledge exists as to what constitutes tortoise habitat, no spatial data models support this knowledge other than geomorphology (Fig. 1a), which is believed to play an important role in limiting tortoise distribution and densities (Weinstein 1989; U.S. Fish and Wildlife Service 1994a; Aycrigg et al. 2004). We ranked landforms to reflect their suitability for tortoise habitat (Fig. 1b). Geomorphic suitability was calculated for each section using an area-weighted average of the different landforms contained within that section (Fig. 1c). 
Table 1 A total of 10 criteria were considered for assessing desert tortoise translocation suitability. Spatial data in support of criteria were obtained from a number of sources

\begin{tabular}{|c|c|}
\hline Criterion & Data source \\
\hline Ownership & $\begin{array}{l}\text { U.S. Bureau of Land Management } \\
\text { (California surface land ownership } \\
\text { http://www.ca.blm.gov/gis) and } \\
\text { supplemented at the section level } \\
\text { with parcel and private ownership } \\
\text { information provided by the NTC }\end{array}$ \\
\hline Habitat & $\begin{array}{l}\text { Earth materials mapping project data } \\
\text { (http://mojavedata.gov; 2000) } \\
\text { and major streams in California } \\
\text { (http://www.ca.blm.gov/gis; 1998) }\end{array}$ \\
\hline $\begin{array}{l}\text { Proximity to major } \\
\text { roads and highways }\end{array}$ & $\begin{array}{l}\text { State of California (U.S. Highways } \\
\text { in California http://gis.ca.gov; 2002) }\end{array}$ \\
\hline $\begin{array}{l}\text { Proximity to urban } \\
\text { areas }\end{array}$ & $\begin{array}{l}\text { ESRI (U.S. Census Urbanized Areas } \\
\text { http://arcdata.esri.com/data/tiger2000/ } \\
\text { tiger_county.cfm?sfips }=06 ; 2000 \text { ) }\end{array}$ \\
\hline $\begin{array}{l}\text { Proximity to } \\
\text { projected } \\
\text { urban growth }\end{array}$ & $\begin{array}{l}\text { State of California (projected urban } \\
\text { growth http://frap.cdf.ca.gov/data/ } \\
\text { frapgisdata/select.asp 2002) }\end{array}$ \\
\hline Road density & $\begin{array}{l}\text { State of California (California local roads, } \\
\text { California State highways, U.S. Highways } \\
\text { in California, Vehicle Trails in California } \\
\text { http://gis.ca.gov; 2002) } \\
\text { U.S. Bureau of Land Management } \\
\text { (route designation west Mojave } \\
\text { plan http://www.blm.gov/ca/cdd/ } \\
\text { wemo.html; 2001) }\end{array}$ \\
\hline Critical habitat units & $\begin{array}{l}\text { U.S. Fish and Wildlife Service } \\
\text { (http://www.fws.gov/nevada/ } \\
\text { desert_tortoise; 1994) }\end{array}$ \\
\hline Off-highway vehicle & $\begin{array}{l}\text { U.S. Bureau of Land Management } \\
\text { (federal off highway vehicle areas, } \\
\text { CA http://www.ca.blm.gov/gis; 1999) }\end{array}$ \\
\hline Die-off regions & $\begin{array}{l}\text { U.S. Bureau of Land Management Total } \\
\text { Corrected Sign tortoise data for 1998, } \\
1999 \text { and } 2001 \text { (U.S. Bureau of Land } \\
\text { Management West Mojave Plan } \\
\text { http://www.blm.gov/ca/cdd/wemo.html; } \\
\text { 2001) } \\
\text { U.S. Fish and Wildlife Service Line } \\
\text { Distance Sampling data 2001-2004 } \\
\text { (U.S. Fish and Wildlife Service } \\
\text { http://www.fws.gov/nevada/ } \\
\text { desert_tortoise; 2006) }\end{array}$ \\
\hline Proximity to NTC & Provided by the NTC \\
\hline
\end{tabular}

Proximity to major roads and highways

Tortoises are known to displace up to $15 \mathrm{~km}$ after translocation (Berry 1986; Nussear 2004), and evidence of tortoise presence is reduced up to $4 \mathrm{~km}$ from major roads (Von Seckendorff Hoff and Marlow 2002; Boarman and Sazaki 2006). Since major roads can be a source of mortality, act as barriers, or at least filter tortoise movement (Gibbs and Shriver 2002; Von Seckendorff Hoff and Marlow 2002), areas $<15 \mathrm{~km}$ from major roads and highways were considered unsuitable and areas $>15 \mathrm{~km}$ suitable. 
Proximity to urban areas

Urban areas are considered poor habitat; thus, translocation suitability increased with distance from such areas.

Proximity to projected urban growth

Translocating tortoises to areas slated for development (i.e., as part of urban planning and projections) would be counterproductive to recovery goals, posing significant future management challenges. Areas within the projected urban growth footprint were considered unsuitable and those outside suitable.

Road density

Within the Mojave Desert, paved and dirt roads have been implicated in the spread of non-native plant species and increased risk of fire (Brooks 1999; Brooks and Pyke 2001). Moreover, roads are known to negatively impact small mammal, lizard, and tortoise populations and habitat (Busack and Bury 1974; Brattstrom and Bondello 1983; Bury and Luckenbach 2002; Von Seckendorff Hoff and Marlow 2002; Boarman and Sazaki 2006), destroy native biological soil crust important for soil stability (Belnap and Eldridge 2001; Belnap 2002), and facilitate human access (Trombulak and Frissell 2000). Unfortunately, access is accompanied by illegal activities such as releasing captive tortoises, collecting, shooting, harassing, etc. The deleterious effects of the increase in roads on tortoise populations have not been explicitly quantified; however, more roads presumably pose a greater level of threat to tortoises. Road density was calculated as the total $\mathrm{km}$ of paved and unpaved roads per section; most roads were unpaved. Areas with more roads were considered less suitable than those with fewer roads (Fig. 2).

Critical habitat

United States Fish and Wildlife Service critical habitat contains physical or biological features considered to be essential to the conservation of a target species (ESA 1973). Areas within desert tortoise critical habitat (U.S. Fish and Wildlife Service 1994b) were considered more suitable than areas outside of critical habitat.

Off highway vehicles

Off highway vehicle activities are detrimental to tortoises by degrading tortoise habitat or crushing tortoises and/or their burrows (Bury and Marlow 1973; Bury and Luckenbach 2002). Therefore, areas designated for open off road vehicle use were considered unsuitable whereas those areas closed to all vehicular traffic or areas where travel was allowed on designated routes only were considered suitable.

Die-off regions

Die-off areas were identified using a custom 2nd order nearest neighborhood analysis of live and carcass observations from U.S. Fish and Wildlife Service monitoring data (2006). A section's die-off score was most influenced by its own score and the score of the eight 1 st 
(a)

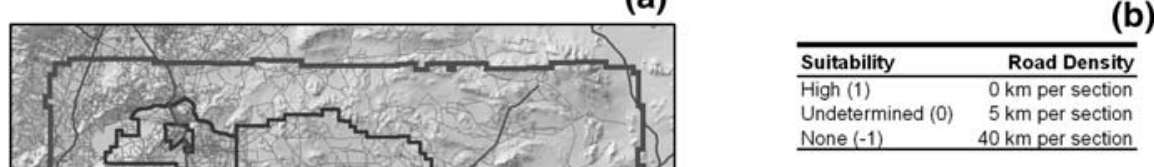

(b)

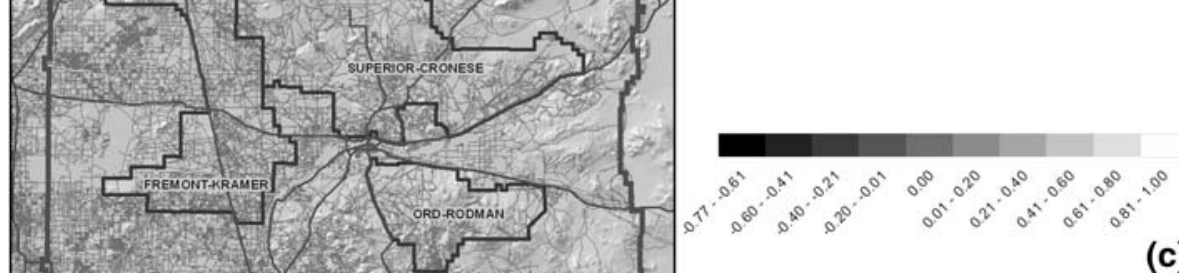

(c)
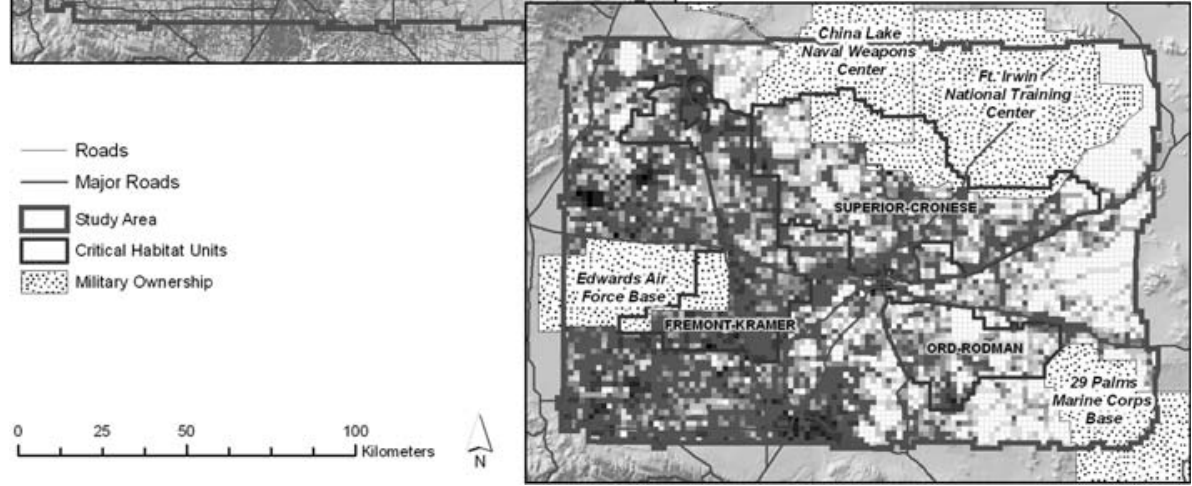

Fig. 2 Road density criteria. (a) Map showing roads source data. (b) Road density model parameters. (c) Suitability for translocation based upon road density. Road density grades from most dense (black) to least dense (white)

order neighbors surrounding it. Less influence was given to the 16-2nd order neighbors surrounding the 1 st order neighbors. Die-off scores ranged from 0 to 12 (i.e., from no evidence to irrefutable evidence of die-off). With the idea of restocking low density areas or repopulating areas altogether, higher die-off scores were considered more suitable than areas with low die-off scores.

\section{Proximity to NTC}

We used proximity to the NTC as a surrogate for actual genetic knowledge. By doing so, we hoped to minimize the disturbance to the population genetics of the resident and translocated populations by giving preference to those areas closer to the NTC. Areas closer to the NTC were deemed more suitable than areas further away.

\section{Factors omitted}

Although additional biological and anthropogenic factors potentially affecting tortoise populations were considered, they were not modeled for the following reasons: (1) little or no potential influence in the study area (e.g., latitude and elevation), (2) no suitable spatial data for modeling existed, and efforts required to secure them were time or cost prohibitive (e.g., raven distribution, nutritional composition and distribution of forage, grazing and soil 
friability), or (3) the spatial resolution of the data were insufficient for detecting meaningful variability (e.g., precipitation).

\section{Relative weighting of criteria}

Criteria were arranged in a logical structure and ranked by level of importance for translocation. The criteria were assigned to one of two tiers and weighted by their relative importance for translocation (Fig. 3). The first tier criteria (ownership, habitat, proximity to major roads and highways, and proximity to urban areas), were regarded as the most influential and weighted more heavily, such that if any one of the parameters were unsuitable that section was considered unsuitable for translocation. The second tier criteria were critical habitat designation, the area's off highway vehicle status, proximity to projected urban growth, die-off ranking, road density, and proximity to NTC. Model scores for the second tier criteria were averaged such that no single criterion rendered a section unsuitable for translocation. However, their combined effect could influence the model. All first and second tier criteria were combined to create a translocation suitability value for each section.

\section{Scenarios}

Alternative scenarios were generated in the Ecosystem Management Decision Support extension based on changes to a criterion's suitability or its exclusion from the model altogether. For example, in one scenario, critical habitat was ignored, while in another, its suitability was reversed. Although parameterization of each criterion differed among scenarios (Table 2), their structure and weights did not. Alternative scenarios were designed to accommodate (1) possible inaccuracies in the source data, e.g., despite concerns over future projected growth, neither the decision makers nor authors had confidence in the projected urban growth data, (2) scientific and management disagreement regarding parameterization of a criterion, e.g., we disagreed on whether die-off areas would be appropriate translocation sites without knowledge

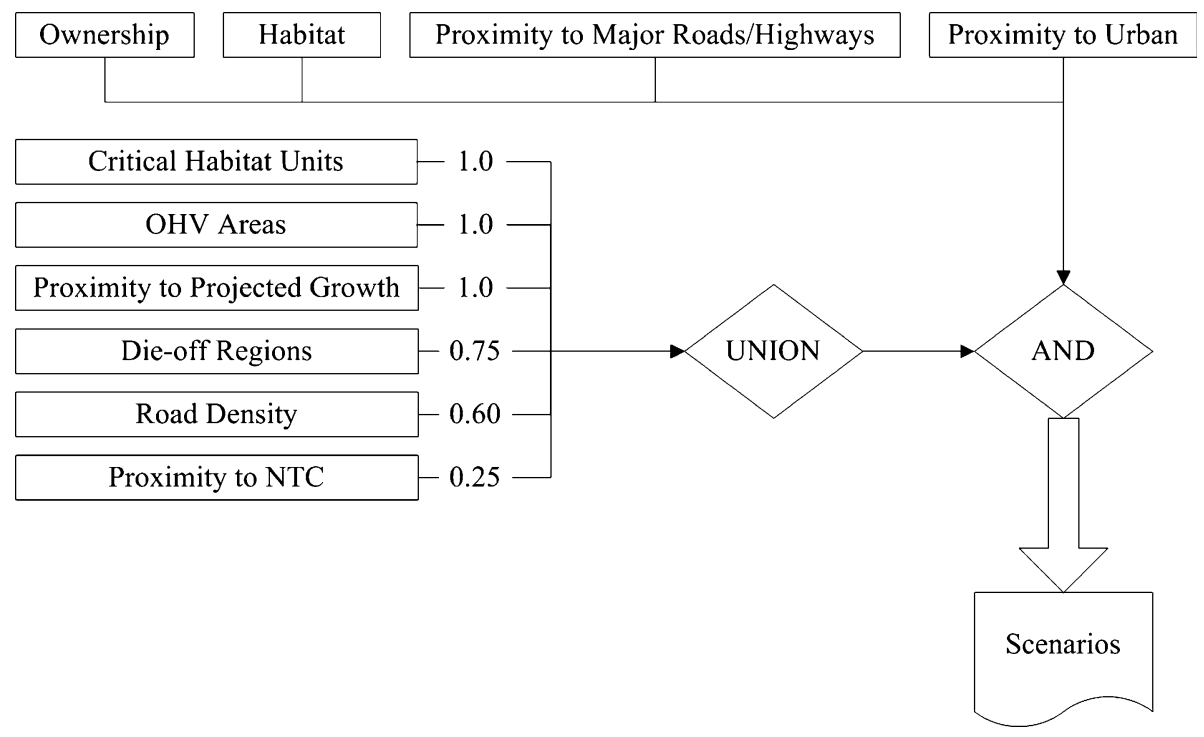

Fig. 3 Criteria model weights used for all scenarios 


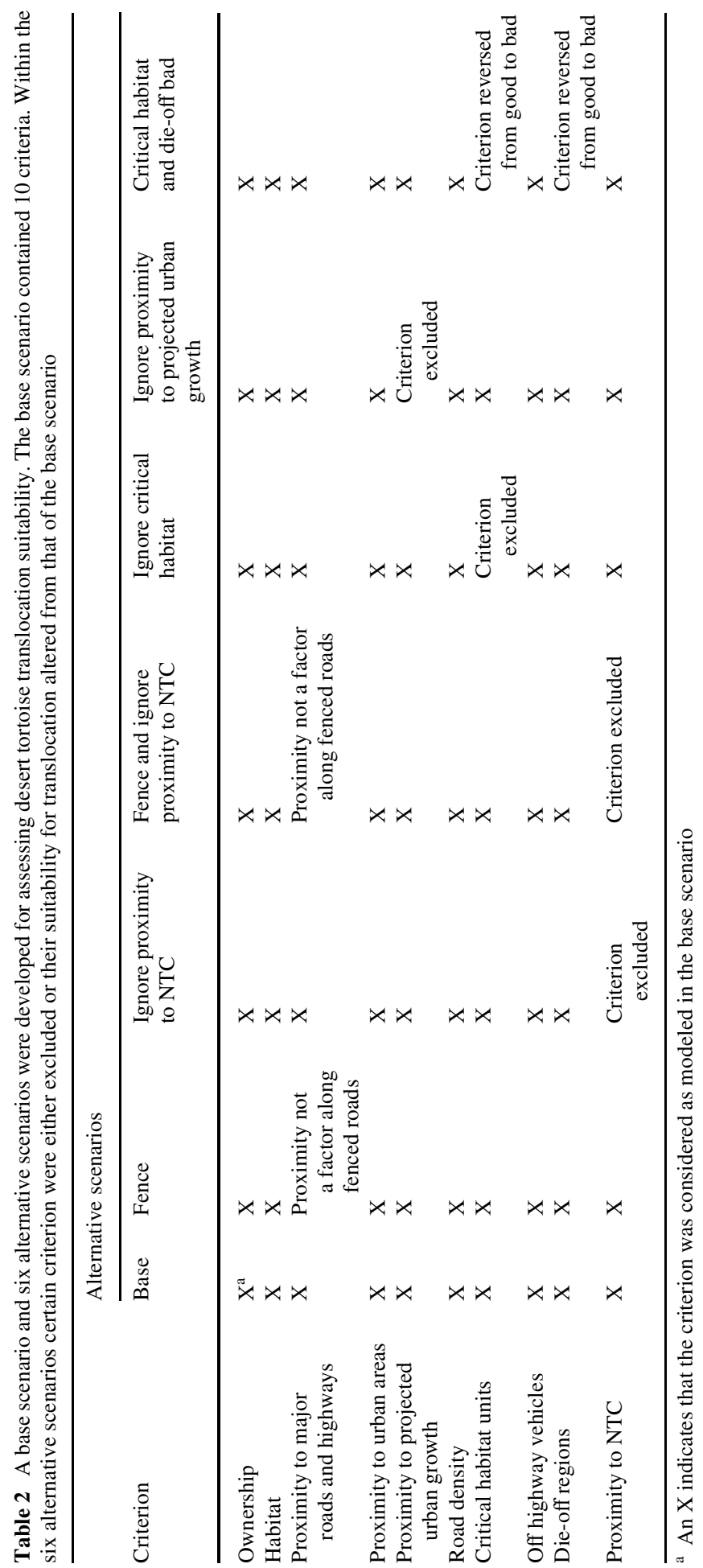


of die-off causes, and whether those threats had been alleviated, or (3) alternative future events, e.g., tortoise fencing versus no fencing of areas along major highways.

\section{Base scenario}

The base scenario was not assumed to be the preferred scenario, but simply the starting point for discussion. All 10 criteria were included in the base scenario with the state of each criterion identified in Table 2.

Fence scenario

This scenario assumed that tortoise-proof fencing would be installed along portions of Interstate 15, Highway 395, Ft. Irwin Road, and Irwin Road, thus removing the negative effects of these roads from the analysis. This was based on the premise that, all other factors being equal, a fenced road prevents tortoise road kills, whereas a non-fenced road provides tortoises no such protection.

Ignore proximity to the NTC

This scenario ignored proximity to the NTC and thus discounted the argument that tortoises should be translocated the shortest distance from their original residence. At the time this model was produced, the limited genetic information indicated that tortoise populations throughout the west Mojave were genetically similar (Lamb et al. 1989; Lamb and McLuckie 2002; Tracy et al. 2004)

Fence and ignore proximity to the NTC

This scenario combined the fence scenario and the ignore proximity to the NTC scenario.

Ignore critical habitat

This scenario ignored the critical habitat criterion. In other words, this scenario gave no preference for or against critical habitat.

Ignore proximity to projected urban growth

This scenario ignored the projected growth criterion.

Critical habitat and die-off bad scenario

In the original base scenario both critical habitat and die-off areas were ranked as suitable for translocation. Under this scenario, however, we reversed that assumption and assumed both to be bad. While the recovery plan states that up to $10 \%$ of any one critical habitat unit could be used for experimental research (U.S. Fish and Wildlife Service 1994a), this recommendation remains controversial, and the scale of this translocation could conceivably encompass more than $10 \%$ of the remaining area (post NTC expansion). Placing tortoises in locations where die-offs have occurred without knowing why those deaths occurred is controversial (Frazer 1992). This scenario assessed the relative influence of these concerns. 
Results were presented to decision makers in a process designed to be open with respect to methods, tools, and data used to rank criteria suitability and to evaluate scenarios. Hard-copy and digital maps, graphics and tables, interactive models, and 3D visualizations of criteria and scenarios were presented to the group for scrutiny and discussion. No single scenario was considered the best scenario, and all seven were combined to create a consensus model. Sections with suitability values $\geq 0.5$ in every scenario represented preferred translocation sites. Sections with suitability values $\leq-0.5$ in any one scenario were considered unsuitable for translocation. All other sections were designated as neutral. For example, if a section had a value $\geq 0.5$ in six of the scenarios, but a value $\leq-0.5$ in the seventh scenario it was considered unsuitable.

\section{Results}

A map was produced for each criterion data, the model parameters assigned for that criterion, and the model results (Figs. 1 and 2). Scenarios were presented to decision makers as in the examples in Fig. 4a-c. This process gave the decision makers the opportunity to use the model predictions as objective products for choosing a series of areas suitable for translocation. Seven possible translocation areas were initially chosen and evaluated during site visits. Six were selected as suitable translocation areas (Fig. 5).

Base Scenario

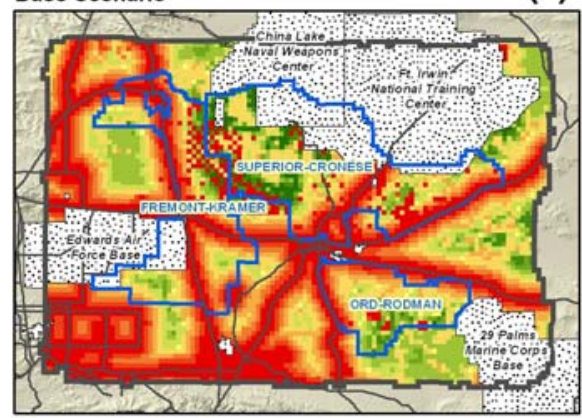

Critical Habitat and Die-off Bad Scenario

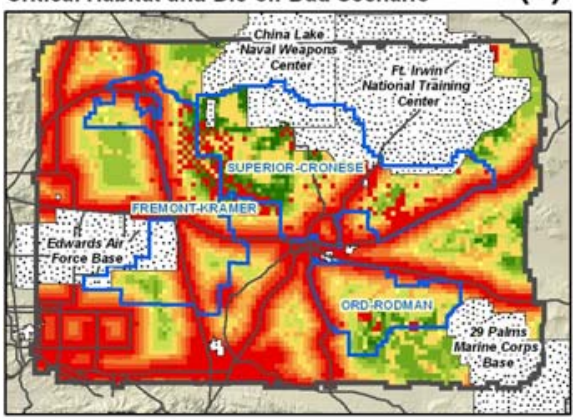

(a)

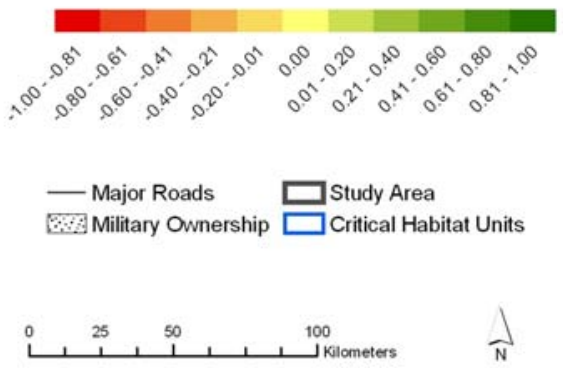

(c)

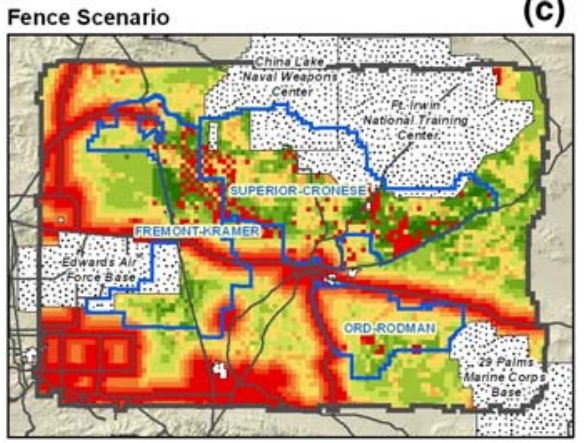

Fig. 4 Graphic of alternative scenarios presented to decision makers. (a) Base scenario. (b) Critical habitat and die-off bad scenario. (c) Fence scenario. The base scenario considers critical habitat and die-off as good and does not factor fenced roads 


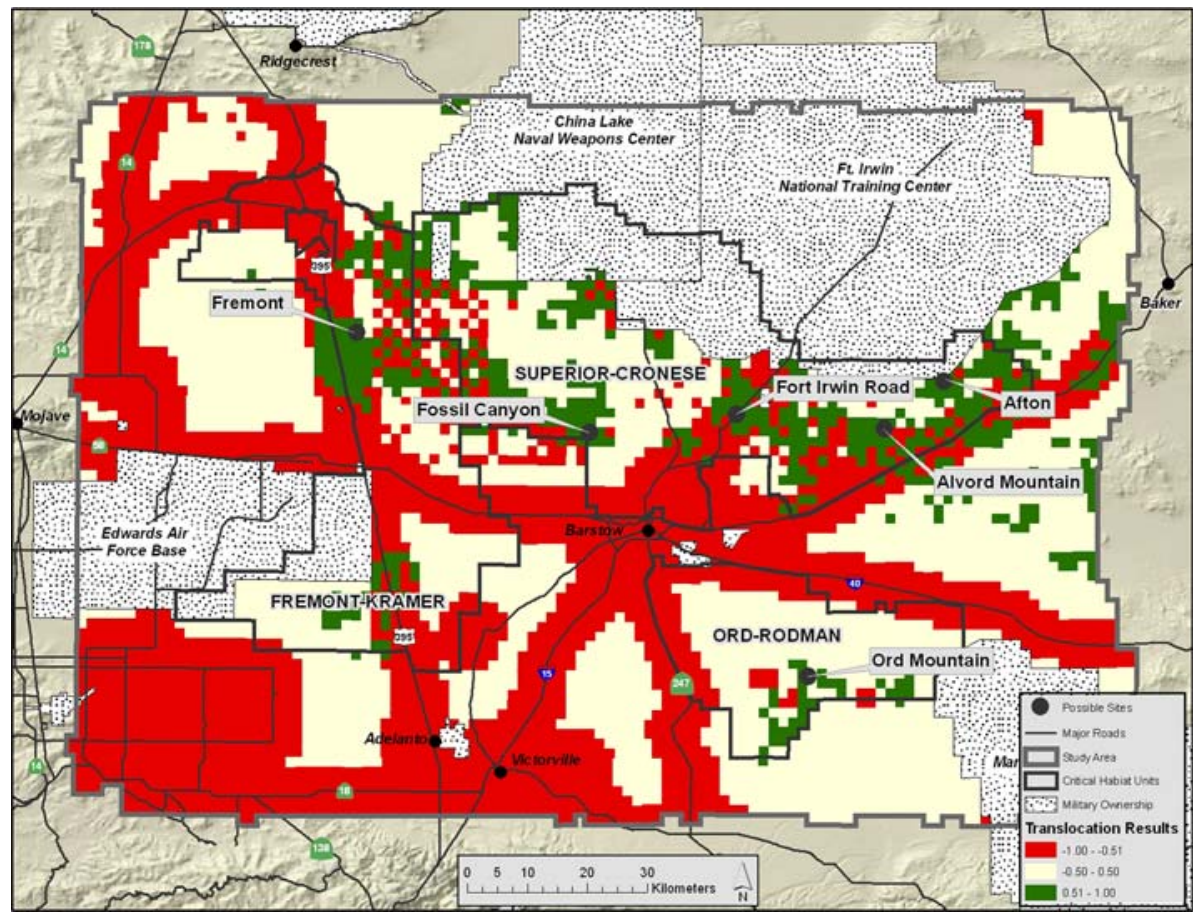

Fig. 5 Final translocation model used for decision making. This map shows the combined common good (green), common bad (red), and common neutral (pale yellow) areas along with the six selected translocation sites

Despite differences of opinion regarding the importance of die-off parameterization (e.g., good versus bad), our modeling outcomes revealed little difference between scenarios relative to the base (Fig. $4 \mathrm{a}, \mathrm{b}$ ). This was due to the greater influence of other criteria, its placement in the second tier of data, and the relative low weight assigned to die-off. This was true for all other scenario comparisons other than fenced roads (Fig. 4a, c). While fencing was never in question as a valid means for preventing tortoise road mortality, this criterion's influence on the model was surprising. Whereas the comparison of the die-off scenarios changed the outcome of only 18 sections, fencing opened up an additional 877 sections as suitable for translocation, a $40 \%$ increase in available translocation area.

\section{Discussion}

Conservation biologists are often faced with the challenge of assisting with the implementation of decisions based upon not only ecological input, but political and social inputs as well. In the case presented here, all three were considered. The decision to allow expansion was contingent upon the translocation of some 2,000 desert tortoises. We implemented a model using spatially explicit decision support system technologies to foster collaboration between scientists and managers.

Neither the collaboration nor the use of decision support system technologies was easy. For every criterion included in the model there were a dozen that were considered and excluded. There were considerable differences of scientific and personal opinion on how 
each criterion should be evaluated. Yet these differences were evaluated objectively through scenarios. The technology we used required significant expertise in geospatial technologies. The project succeeded because geospatial, desert tortoise and management expertise were brought together in a collaborative environment. The results of this work (1) provided an objective, open, scientifically credible process that ranked translocation suitability by consensus on habitat and conservation-based criteria, (2) produced seven alternative translocation scenarios from which a single best consensus translocation model was generated, and (3) identified six potential translocation sites.

Objectivity and scientific credibility were achieved in the selection and approval of model criteria using a decision support model based on scientific literature, expert opinion, and peer-review (Esque et al. 2005), with feasibility ultimately vetted by managers. Openness was achieved through the development of alternate scenarios as well as recognition that "conservation is primarily not about biology but about people and the choices they make" (Balmford and Cowling 2006). The consequences of these choices were assessed by modeling alternative scenarios to (1) explore differences of opinion, (2) review consequences of alternative management actions, and (3) explore uncertainty in data.

The process, methods, and tools of the decision support system technologies used in this research integrated key concepts in conservation biology and natural resource management (Kessler and Thomas 2006) and ultimately led to its successful implementation. First, we drew from a wide array of scientific expertise and management perspectives. Second, instead of a theoretical decision support system with no real management application, we addressed an urgent, complex management need that required a practical solution-the translocation of desert tortoises - using the best available scientific information. Third, we addressed this problem by tackling a critical challenge that faces conservation biology today and in the foreseeable future: the development of spatially explicit models for addressing natural resource management needs (Balmford et al. 2005; Balmford and Cowling 2006). Fourth, the process was engaging and used visually compelling and easily understandable graphical formats (Sheppard and Meitner 2005).

Translocation, along with land acquisition, fencing, retirement of grazing allotments, research funding, and route designation and closure, were all identified as mitigation measures to offset the impacts of expansion (U.S. Fish and Wildlife Service 2004). The decision support system developed here could be used for other desert tortoise management and mitigation needs, in particular in the area of additional decision making, adaptive management and/or evaluation of criteria affected by management decisions. This system influenced the decision to fence additional roads. Fencing was originally recommended as a measure to mitigate expansion, but was expected to only occur in a very limited area. As a result of scenario evaluation, its importance was elevated, and extensive fencing is now anticipated along areas of Interstate 15 prior to or in conjunction with translocation. Besides fencing, this system could be used to identify purchasable lands. This could be done by evaluating the number of private owners per section, a logistical factor, the translocation suitability of that section, and the quality of the surrounding lands. In addition, after each land purchase the system could easily be updated and the translocation suitability of each section within the study area recalculated. Because this system is adaptive it could provide real-time updates to translocation suitability and more importantly could lead to what-if land purchase scenarios.

Tortoises will be translocated from the expansion area in two phases. The first phase is expected to included 800 or more individuals. Because this system is adaptive, it could be updated either at the criterion suitability level or scenario level based upon the outcome of the initial translocation. For example, if tortoises in the first phase of translocation move 
greater than or less than $15 \mathrm{~km}$ from their initial release sites, distance from major roads or highways could be adjusted accordingly prior to the second translocation. Third, as new knowledge and data are acquired, especially spatial data, additional criteria can be added or the data supporting a single criterion updated.

Decision support systems, especially spatially explicit ones, are beginning to play an increasing role in natural resources management. However, conservation biologists must be cognizant of the risk of developing decision support systems, for the sake of the scientific exercise, that lack a connection to on-the-ground management needs. Developers of these systems, at least those who intend to affect management, are wasting time and money if their systems are built in the absence of manager and/or stakeholder participation, if appropriate. The system presented here was successful, with success being measured by the degree to which management decisions were based upon the model recommendations, because both scientists and managers invested in the system, and collectively contributed to its design, build and implementation.

Acknowledgements This work was supported in part by funds provided by: the U.S. Army Research Lab Army Research Office under grant number DAAD19-01-1-0793 and with funds provided by the National Training Center at Fort Irwin. We thank the Conservation Mitigation Working Group whose members included B. Jones and G. Black-California Department of Fish and Game; C. Sullivan, B. Gonzales, R. Trost-U.S. Bureau of Land Management; R. Bransfield, D. Threloff and R. Averill-Murray-U.S. Fish and Wildlife Service; D. Delaney and L. Pater-U.S. Department of Army Construction Engineering Research Lab; P. Kernek, K. Rainey, A. Rekas, N. Lynn, M. Quillman and R. Marler-U.S. Department of the Army National Training Center at Fort Irwin. T. Lamb and an anonymous reviewer provided valuable comments and increased the quality of this manuscript.

\section{References}

Aycrigg JL, Harper SJ, Westervelt JD (2004) Simulating land use alternatives and their impacts on a desert tortoise population in the Mojave Desert, California. In: Costanza R, Vionov A (eds) Landscape simulation modeling: a spatially explicit, dynamic approach. Springer-Verlag, New York, pp 249-274

Balmford A, Cowling RM (2006) Fusion or failure? The future of conservation biology. Conserv Biol 20:292-255

Balmford AP, Crane AP, Dobson RE, Green, Mace GM (2005) The 2010 challenge: data availability, information needs, and extraterrestrial insights. Phil Trans R Soc B: Biol Sci 360:221-228

Belnap J (2002) Impacts of off-road vehicles on nitrogen cycles in biological soil crusts: resistance in different U.S. deserts. Journal of Arid Environments 52:155-165

Belnap J, Eldridge DJ (2001) Disturbance and recovery of biological soil crusts. In: Belnap J, Lange OL (eds) Biological soil crusts: structure, function, and management. Springer-Verlag, New York, pp 363-384

Berry KH (1986) Desert tortoise (Gopherus agassizii) relocation: implications of social behavior and movements. Herpetologica 42:113-125

Boarman WI, Sazaki M (2006) A highway's road-effect zone for desert tortoises (Gopherus agassizii). J Arid Environ 65:94-101

Brattstrom BH, Bondello MC (1983) Effects of off-road vehicle noise on desert vertebrates. In: Webb RH, Wilshire HG (eds) Environmental effects of off-road vehicles: impacts and management in arid lands. Springer-Verlag, New York, pp 167-206

Brooks ML (1999) Alien annual grasses and fire in the Mojave Desert. Madrono 46:13-19

Brooks ML, Pyke D (2001) Invasive plants and fire in the deserts of North America. In: Galley K, Wilson T (eds) Proceedings of the invasive species workshop: the role of fire in the control and spread of invasive species fire conference 2000: the first national congress on fire, ecology, prevention and management. Miscellaneous Publications No. 11 Tall Timbers Research Station, Tallahassee, Florida, pp 1-14

Bury RB, Luckenbach RA (2002) Comparison of desert tortoise (Gopherus agassizii) populations in an unused and off-road vehicle area in the Mojave Desert. Chelonian Conserv Biol 4:457-463

Bury RB, Marlow RW (1973) The desert tortoise: will it survive? Natl Parks Conserv Mag 47:9-12

Busack SD, Bury RB (1974) Some effects of off-road vehicles and sheep grazing on lizard populations in the Mojave Desert. Biol Conserv 6:179-183 
Endangered Species Act, The (ESA), 1973. 16 USC

Esque TC, Nussear KE, Medica PA (2005) Desert tortoise translocation plan for Fort Irwin's land expansion program at the U.S. Army National Training Center (NTC) at Fort Irwin. Prepared for U.S. Army National Training Center, Directorate of Public Works. http://www.fortirwinlandexpansion.com/Documents.htm (accessed March 2006)

Frazer J (1992) Sea turtle conservation and halfway technology. Conserv Biol 6:179-184

Gibbs JP, Shriver G (2002) Estimating the effects of road mortality on turtle populations. Conserv Biol $16: 1647-1652$

Girvetz E, Shilling F (2003) Decision support for road system analysis and modification on the Tahoe National Forest. Environ Manage 32:218-233

Kessler WB, Thomas JW (2006) Conservation biology from the perspective of natural resource management disciplines. Conserv Biol 20:670-673

Lamb T, Avise JC, Gibbons JW (1989) Phylogeographic patterns in mitochondrial DNA of the desert tortoise (Xerobates agassizii), and evolutionary relationships among North American gopher tortoises. Evolution 43:76-87

Lamb T, McLuckie AM (2002) Genetic differences among geographic races of the desert tortoise. In: Van Devender TR (ed) The sonoran desert tortoise: natural history, biology, and conservation. University of Arizona Press, Tucson, pp 67-85

Leung Y (1997) Intelligent spatial decision support systems. Springer-Verlag, Berlin

Llewellyn DW, Shaffer GP, Craig NJ, Creasman L, Pashley D, Swan M, Brown C (1996) A decision-support system for prioritizing restoration sites on the Mississippi River alluvial plain. Conserv Biol 10:1446-1455

Meesters EH, Bak RPM, Westmacott S, Ridgley M, Dollar S (1998) A fuzzy logic model to predict coral reef development under nutrient and sediment stress. Conserv Biol 12:957-965

Nussear KE (2004). Mechanistic investigation of the distributional limits of the desert tortoise, Gopherus agassizii. Unpublished Ph.D. thesis. University of Nevada, Reno

Openshaw S (1996) Fuzzy logic as a new scientific paradigm for doing geography. Environ Plan A 28:761768

Public Law 106-554 (2001) Consolidated Appropriations Act, 2001. Incorporates by reference H.R. 5666 Sec 323 Miscellaneous Appropriations 146 Congressional Record H12262, December 15, 2000

Public Law 107-314 (2002) Bob Stump National Defense Authorization Act for Fiscal Year 2003. Incorporates by reference Title XXIX Fort Irwin Military Lands Withdrawal Act of 2001

Rauscher HM (1999) Ecosystem management decision support for federal forests in the United States: a review. For Ecol Manage 114:173-197

Reeves GH, Williams JE, Burnett KM, Gallo K (2006) The aquatic conservation strategy of the Northwest Forest Plan. Conserv Biol 20:319-329

Reynolds KM (2001) Fuzzy logic knowledge bases in integrated landscape assessment: examples and possibilities. Gen. Tech. Rep. PNW-GTR-521. Portland, OR: U.S. Department of Agriculture, Forest Service, Pacific Northwest Research Station. $24 \mathrm{p}$

Reynolds KM, Hessburg PF (2005) Decision support for integrated landscape evaluation and restoration planning. For Ecol Manage 207:263-278

Reynolds K, Cunningham C, Bednar L, Saunders M, Foster M, Olson R, Schmoldt D, Latham D, Miller B, Steffenson J (1996) A knowledge-based information management system for watershed analysis in the Pacific Northwest U.S. AI Applic 10:9-22

Reynolds KM, Johnson KN, Gordon SN (2003) The science/policy interface in logic-based evaluation of forest ecosystem sustainability. For Policy Econ 5:433-446

Riordan R, Barker K (2003). Cultivating biodiversity in Napa. Geospatial Solut 2003:30-35

Saunders MC, Sullivan TJ, Nash BL, Tonnessen KA, Miller BJ (2005) A knowledge-based approach for classifying lake water chemistry. Knowl based syst 18:47-54

Sheppard RJ, Meitner M (2005) Using multi-criteria analysis and visualization for sustainable forest management planning with stakeholder groups. For Ecol Manage 207:171-187

Sprague R (1986) A framework for development of decision support systems. In: Sprague R, Watson H (eds) Decision support systems: putting theory into practice. Prentice-Hall, London, pp 7-32

Tracy CR, Averill-Murray R, Boarman WI, Delehanty D, Heaton JS, McCoy E, Morafka D, Nussear K, Hagerty B, Medica P (2004). Desert tortoise recovery plan assessment. Report submitted to the U.S. Fish and Wildlife Service. http://www.fws.gov/nevada/desert_tortoise/dt_reports.html (accessed March 2006)

Trombulak SC, Frissell A (2000) Review of ecological effects of roads on terrestrial and aquatic communities. Conserv Biol 14:18-30

Twedt DJ, Uihlein WB III, Elliott AB (2006) A spatially explicit decision support model for restoration of forest bird habitat. Conserv Biol 20:100-110 
U.S. Fish and Wildlife Service (USFWS) (1994a) Desert tortoise (Mojave population) Recovery Plan. USFWS, Portland, Oregon. 73 pp, plus appendices

U.S. Fish and Wildlife Service (USFWS) (1994b) Endangered and threatened wildlife and plants: proposed determination of critical habitat for the Mojave population of the desert tortoise. 50 CFR, part 17. Fed Regist 58:45748-45768

U.S. Fish and Wildlife Service (USFWS) (2004) Biological opinion for the proposed addition of maneuver training lands at Fort Irwin, California. (1-8-03-F-48) March 15, 2004. 67 pp, plus references

U.S. Fish and Wildlife Service (USFWS) (2006) Review draft monitoring report. USFWS, Portland, Oregon. http://www.fws.gov/nevada/desert_tortoise/dt_reports.html (accessed March 2006)

Von Seckendorff Hoff K, Marlow RW (2002) Impacts of vehicle road traffic on desert tortoise populations with consideration of conservation of tortoise habitat in southern Nevada. Chelonian Conserv Biol 4:449-456

Weinstein MN (1989) Modelling desert tortoise habitat: can a useful management tool be developed from existing transect data? Unpublished Ph.D. thesis. University of California, Los Angeles

Zadeh L (1968) Probability measures of fuzzy events. J Math Anal Applic 23:421-427 